\title{
Geskrewe en gesproke Afrikaanse Sintaktiese Vermoëns van Hardhorende Kinders
}

\author{
Enid Slabber, B(Log) (Pretoria) \\ René Hugo, D.Phil (Pretoria) \\ Brenda Louw, D.Phil (Pretoria) \\ Departement Spraakheelkunde en Oudiologie, \\ Universiteit van Pretoria
}

\begin{abstract}
OPSOMMING
Die doel van hierdie ondersoek is om 'n moontlike verband tussen ekspressiewe geskrewe en gesproke sintaktiese vermoëns van gehoorgestremdes te ondersoek. Vyf Afrikaanssprekende gehoorgestremde proefpersone is gebruik. In die evaluering van sintaktiese vermoëns is daar gekyk na die gebruik van 7 sinstrukture asook na woordvolgorde. Uit die resultate blyk dit dat meer komplekse sinstrukture tydens die proefpersone se gesproke as geskrewe taal voorgekom het. Die persentasie korrekte sinstrukture wat gebruik is, is egter groter in geskrewe as in gesproke taal, alhoewel die persentasie nogtans betreklik laag is. Meer woordvolgordefoute is tydens geskrewe as gesproke taal gemaak. In die gebruik van die geëvalueerde sinstrukture het daar egter meer woordvolgordefoute in gesproke as geskrewe taal voorgekom.
\end{abstract}

Die gevolgtrekking is bereik dat daar wel 'n verband tussen die gehoorgestremde proefpersone se geskrewe en gesproke sintaktiese taalvermoëns is, maar heelwat verskille het ook voorgekom. Navorsing op hierdie gebied lê egter nog braak, en die huidige studie kan as ver. trekpunt dien vir verdere navorsing.

\section{ABSTRACT'}

The aim of this research report is to examine the relationship between the expressive written and spoken syntactic abilities of hearingimpaired children. 5 Afrikaans speaking hearing-impaired subjects were used. In the evaluation of syntactic abilities, 7 syntactical structures as well as word order, were evaluated. From the results obtained, it appeared that more complex sentence structures were used in spoken than in written language. The percentage structures used correctly, was higher in written than in spoken language, although the percentage was relatively low. More errors of word order occurred in written than in spoken language, but subjects evidenced more word order errors in spoken than in written language, when using more complex sentences. The conclusion is made that a relationship between written and spoken syntactic abilities of hearing-impaired subjects does exist, but differences were also evidenced. The study can be used as a "starting point" for further, research.

\section{INLEIDING}

Normale gehoor is essensieel vir normale taalverwerwing en gevolglik vertoon gehoorgestremde kinders deurgaans taalprobleme (reseptief en ekspressief) wat op verskillende taalvlakke en in verskillende grade manifesteer en hulle kommunikasievermoëns nadelig beïnvloed (Davis en Hardick, 1981). Wanneer daar na'kommunikasie verwys word, sluit dit enige wyse in waardeur die persoon sy voorgenome boodskap oordra. Die uitdrukking van 'n boodskap kan deur middel van gebare, gesproke of geskrewe taal plaasvind. Ekspressiewe taal (hetsy geskrewe of oraal) is vir die gehoorgestremde kind 'n probleem wat oorkom moet word ten einde die beperking op kommunikasievermoëns op te hef of te verminder. Hierdie feit is algemeen bekend, maar wat die verband tussen die twee ekstreme vorme, naamlik geskrewe en gesproke taal is, en wat die implikasies daarvan vir die spraakterapeut/oudioloog in die evaluering en behandeling van die gehoorgestremde kind is, is vrae wat nog beantwoord moet word.
Navorsingsbelangstelling is gerig op sowel geskrewe en resproke taalvermoëns van gehoorgestremdes, maar outeurs bestudeer geskrewe en gesproke taal gewoonlik apart. Beperkte navorsing is uitgevoer in terme van 'n vergelyking van geskrewe en gesproke taalvermoëns (Arnold, Crossley en Exley, 1982; Power en Wilgus, 1983). Beskikbare data dui egter dat daar op alle taalvlakke beide ooreenkomste en verskille tussen gesproke en geskrewe taalvaardighede van gehoorgestremde kinders gevind is (Arnold, Crossley, Exley, 1982; Power en Wilgus, 1983; Myklebust, 1965).

Die doel van hierdie artikel is om die ekspressiewe geskrewe en gesproke sintaktiese vaardighede van gehoorgestremdes te bestudeer. Sodoende word gepoog om 'n moontlike verband tussen die twee modaliteite te bepaal, en om die verkreë inligting as moontlike riglyn tydens die evaluering en behandeling van die sintaksis van gehoorgestremdes aan te wend.*

\footnotetext{
VOETNOOT

- Die gebruik van gebaretaal as kommunikasiemiddel deur gehoorgestremde kinders word erken maar word nie in hierdie ondersoek in berekening gebring nie aangesien slegs die geskrewe en gesproke vorms van Afrikaans as verskynsel by gehoorgestremde kinders ondersoek
} word. 


\section{METODE}

\subsection{Proefpersoonseleksie}

Tydens die seleksie van proefpersone is die Standerd 4 a en $b$ en Standerd 5 a en b klasse van 'n bepaalde skool vir hardhorendes gebruik. Op grond van bepaalde kriteria is 5 proefpersone uit 'n aantal van 70 kinders geselekteer, deur die lêers van die 70 leerlinge na te gaan. Die onderwyseres, spraakterapeut en sielkundige se menings is ook ingewin, om sodoende geldigheid van seleksie te verseker. Die relevante kenmerke van die 5 kinders wat uiteindelik geselekteer is, word in Tabel 1 aangedui.

Tabel 1: Beskrywing van die relevante eienskappe van die geselekteerde proefpersone

\begin{tabular}{|c|c|c|c|c|c|}
\hline \multirow[t]{2}{*}{ Kriteria vir seleksie } & \multicolumn{5}{|c|}{ Proefpersoonnommer } \\
\hline & & & 3 & & \\
\hline Skoolplasing & \\
\hline Taal & \multicolumn{5}{|c|}{ Afrikaans } \\
\hline Geslag & \multicolumn{5}{|c|}{ Manlik } \\
\hline Dra van gehoorapparaat & \multirow{2}{*}{\multicolumn{5}{|c|}{ Saktipe }} \\
\hline $\begin{array}{l}\text { Graad van gehoorverlies } \\
\text { igemiddelde suiwertoondrempel) }\end{array}$ & & & & & \\
\hline Linkeroor (dB) & 95 & 95 & 95 & 100 & 75 \\
\hline Regteroor (dB) & 80 & 90 & 95 & 80 & 100 \\
\hline Intelligensie & \multicolumn{5}{|c|}{ Gemiddeld } \\
\hline Invloed van stimulasie & \multicolumn{5}{|c|}{ Dagskolier } \\
\hline Meervoudige gestremdheid & \multicolumn{5}{|c|}{ Geen } \\
\hline Kongenitale gehoorverlies & \multicolumn{5}{|c|}{$\mathrm{Ja}$} \\
\hline Normaalhorende ouers & \multicolumn{5}{|c|}{$\mathrm{Ja}$} \\
\hline Ouderdomme in jare en maande & \multicolumn{5}{|c|}{$\begin{array}{lllll}12.8 & 13.1 & 12.0 & 12.8 & 12.0\end{array}$} \\
\hline
\end{tabular}

\subsection{Materiaal}

'n Toets vir die evaluering van Afrikaanssprekende gehoorgestremde kinders se ekspressiewe geskrewe en gesproke taalvermoëns is opgestel, aangesien geen bestaande toetse aan die gestelde vereistes voldoen het nie.

\subsubsection{Teoretiese basis waarop die toets berus}

Die benadering tot taalontwikkeling en taalafwykings wat deur Bloom en Lahey (1978) voorgestel is, word aangehang. Hiervolgens bestaan taal uit drie komponente, naamlik taalinhoud, taalvorm en taalgebruik. Die komponente wat deur Bloom en Lahey (1978) gedefinieer word, bied 'n raamwerk vir die evaluering van taalontwikkeling, en kan sinvol in die samestelling van die toets gebruik word. Taalgebruik is egter nie in hierdie ekspriment geëvalueer nie, aangesien dit moeilik toetsbaar is in geskrewe taal. In die breë kan die basis waarop die toets berus skematies (sien Figuur 1) voorgestel word.

\subsubsection{Toets vir die evaluering van Afrikaanssprekende gehoor- gestremde kinders se ekspressiewe geskrewe en gesproke vermoëns.}

Die toets vir die evaluering van Afrikaanssprekende gehoorgestremde kinders se ekspressiewe geskrewe en gesproke vermoëns, het beide geskrewe en gesproke taalvorm (sintaksis, morfologie en fonetiek) en taalinhoud (produktiwiteit, woordsoorte, aard) geëvalueer, asook aanvullende inligting

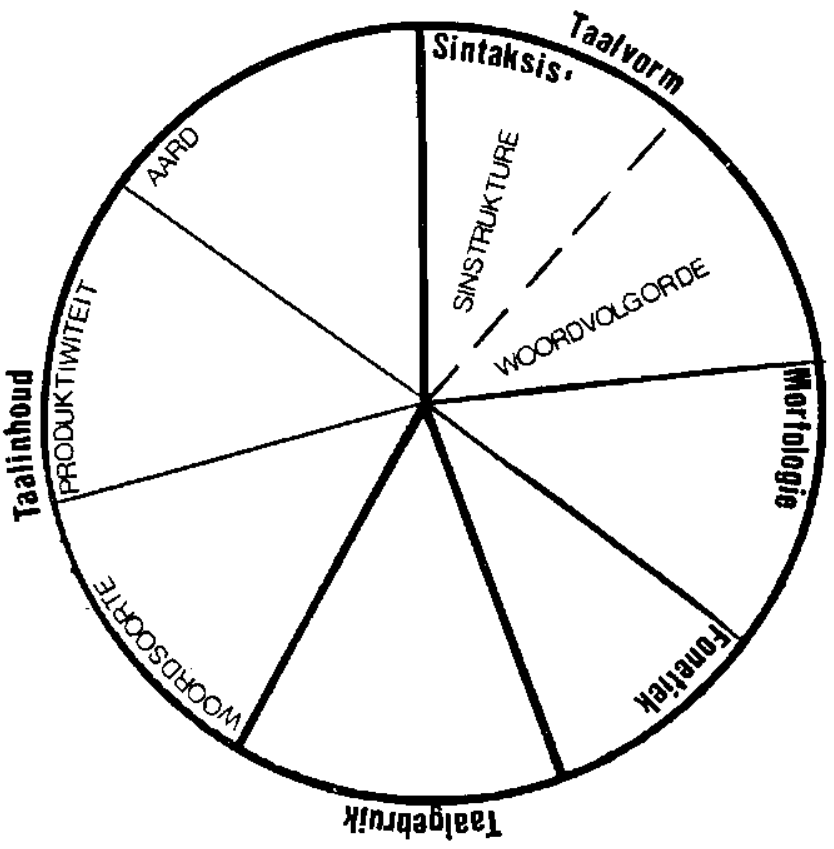

Figuur 1: Skematiese voorstelling van toetsinhoud.

oor taalvermoëns verskaf. ' $n$ Volledige uiteensetting van die toets met al sy onderafdelings word in Bylae A verskaf. Hierdie artikel verskaf egter net 'n bespreking van die sintaktiese vermoëns van die proefpersone aangesien Quigley, Montanelli en Wilbur (1976) meen dat sintaktiese vermoëns beskou kan word as ' $n$ verteenwoordigende weerspieëling van die gehoorgestremde kind se, vlak van ekspressiewe taalfunksionering.

In die evaluering van sintaktiese vermoëns, is twee aspekte, naamlik sinstrukture en woordvolgorde bestudeer.

\section{a) Sinstruktuur}

Hierdie afdeling omsluit die gebruik van die ingebedde sin, newe en onderskikkende sin, vraagsin, ontkenningsin, passiewe sin, onvoltooide sin, korrekte tydvorm van die sin en die gebruik van die direkte rede. Hier word dus gekyk na die verskillende sinstrukture wat die gehoorgestremde kind korrek kan gebruik (Arnold 1978; Bunch 1979; Powers en Wilgus, 1983; Steinkamp en Quigley, 1977; Pressnell, 1973; Ivimey, 1976; Wilbur, Goodhart en Montandon, 1983).

\section{b) Woordvolgorde}

Met foutiewe woordvolgorde word enige omruilings van twee of meer woorde, of slegs een woord wat in 'n verkeer-' de posisie in die sin gebruik word, bedoel. Woordvolgorde is belangrik, aangesien dit ' $n$ invloed het op die sinstruktuur en sintaktiese korrektheid daarvan. Aangesien gehoorgestremdes geneig is om probleme met woordvolgorde te hê, is dit ook by hierdie studie ingesluit (Myklebust, 1965).

\subsubsection{Ontlokkingsprosedure}

Beide geskrewe en gesproke taalvaardighede is afsonderlik ontlok deur prentbeskrywingstake. Duidelike mondelinge instruksies is aan die proefpersone verskaf om 'n storie oor die voorgehoue prente te skryf en verbal te vertel.

\subsubsection{Analise-prosedure}

Sintaksis is geëvalueer deur die strukture in elke sin te 
beoordeel ten opsigte van die frekwensie van voorkoms, korrekte woordvolgorde, weglating, vervanging of byvoeging van woorde in spesifieke sinstrukture gebruik.

Woordvolgorde is kwantitatief sowel as kwalitatief geëvalueer en volgordefoute word met die strukture in die res van die $\sin$ in verband gebring. Sodoende kan ' $n$ duideliker beeld verkry word van wanneer die woordvolgorde in ' $n$ sin verkeerd is, byvoorbeeld altyd saam met die gebruik van 'n voegwoord of voorsetsel, ensovoorts.

\subsection{Prosedure}

- Vyf proefpersone is geselekteer op grond van gestelde kriteria.

- $\quad$ 'n Voorstudie is met 'n enkele proefpersoon uitgevoer en aanpassings op grond van die resultate wat verkry is, is gemaak.

- By die toepassing van die finale weergawe van die toets op vyf proefpersone is geskrewe taalvaardighede eerste geëvalueer om proefpersone sodoende meer op hulle gemak te stel.

- Gesproke taalvaardigheid is een week later geëvalueer, sodat die herhalingseffek uitgeskakel kon word.

\section{RESULTATE EN BESPREKING}

Die verkreë resultate van die proefpersone se geskrewe en gesproke sintaktiese vermoëns word vervolgens bespreek.

\subsection{Sinstrukture}

Die gegewens in verband met die tipe sinstrukture wat deur die proefpersone tydens die gesproke en geskrewe taal gebruik is, word in Tabelle 2, 3 en 4 weergegee.

Tabel 2 verskaf ' $n$ uiteensetting van die geëvalueerde sin strukture wat deur die proefpersone tydens gesproke en geskrewe taal gebruik is. In Tabel 3 word opsommende inligting áangaande die geëvalueerde sinstrukture vervat. Tabel 4. dui die voorkoms van persentasie foutiewe sinsvorme tydens gesproke en geskrewe taal aan.

Tabel 2: Geëvalueerde sinstrukture wat deur die proefpersone tydens gesproke en geskrewe taal gebruik is

\begin{tabular}{|l|c|c|c|c|c|c|}
\hline \multirow{2}{*}{ Sinstrukture } & \multicolumn{3}{|c|}{ Geskrewe taal } & \multicolumn{4}{c|}{ Gesproke taal } \\
\cline { 2 - 7 } & A & B & C & A & B & C \\
\hline Ingebedde sin & 0 & 0 & 0 & 0 & 0 & 0 \\
Onderskikkende sin & 6,3 & 20 & 0 & 2 & 100 & 0 \\
Neweskikkende sin & 16,5 & 84,6 & 0 & 12,7 & 77 & 7,6 \\
Vraagsin & 1,3 & 0 & 0 & 3 & 100 & 0 \\
Ontkenningsin & 6,3 & 80 & 0 & 9,8 & 40 & 10 \\
Passiewe sin & 1,3 & 0 & 100 & 0 & 0 & 0 \\
Direkte rede & 1,3 & 100 & 0 & 17,6 & 5,6 & 5,5 \\
\hline
\end{tabular}

A - persentasie sinstrukture gebruik

B - persentasie sinstrukture korrek gebruik

C - persentasie foutiewe woordvolgorde

Uit Tabel 2 word afgelei dat die sinstrukture wat die meeste voorgekom het tydens geskrewe taal, die neweskikkende
Tabel 3: Opsommende inligting aangaande sinstrukture

\begin{tabular}{|l|c|c|}
\hline & Geskrewe taal & Gesproke taal \\
\hline $\begin{array}{l}\text { Totale aantal sinne gebruik } \\
\text { Totale persentasie geëva- } \\
\text { lueerde sinstrukture } \\
\text { Persentasie t-eenhede nie } \\
\text { geëvalueer } \\
\begin{array}{l}\text { Persentasie korrekte sin- } \\
\text { strukture }\end{array}\end{array}$ & 79 & 102 \\
$\begin{array}{l}\text { Persentasie woordvolgorde- } \\
\text { foute in die gebruik van } \\
\text { geëvalueerde sinstrukture }\end{array}$ & $67,1 \%$ & $45,1 \%$ \\
\hline
\end{tabular}

Tabel 4: Voorkoms van persentasie foutiewe sinsvorme tydens gesproke en geskrewe taal

\begin{tabular}{|l|c|c|}
\hline Foutiewe sinsvorme & $\begin{array}{c}\text { \% voorkoms in } \\
\text { geskrewe taal }\end{array}$ & $\begin{array}{c}\text { \% voorkoms in } \\
\text { gesproke taal }\end{array}$ \\
\hline Onvoltooide sinne & 3,8 & 2 \\
Tyd-vorm foutief & 1,3 & 0 \\
\hline
\end{tabular}

$(16,5 \%)$, onderskikkende $(6,3 \%)$ en ontkenningsinne $(6,3 \%)$ was. Ingebedde sinne kom glad nie voor nie, terwyl direkte rede, vraagsinne en passiewe sinne slegs 'n voorkomsfrekwensie van $1,3 \%$ getoon het. Die sinstrukture wat die grootste persentasie korrekte voorkoms getoon het, was direkte rede (100\% korrek), ontkenningsinne $(80 \%$ korrek) en neweskikkende sinne $(84,6 \%$ korrek $)$. Slegs $20 \%$ van die onderskikkende sinne is korrek gebruik. Volgens Tabel 3 bestaan $32,9 \%$ van die uitinge uit die sewe tipes sinstrukture wat in Tabel 2 genoem word en daarvan is $65,4 \%$ korrek gebruik, terwyl slegs $3,8 \%$ van die bepaalde sinstrukture woordvolgordefoute getoon het.

Volgens Tabel 2 is die sinstruktuur wat die hoogste voor komsfrekwensie van die sewe tipes strukture getoon het tydens geskrewe taal neweskikkende sinne $(16,5 \%)$. Hierdie waarneming kan moontlik verklaar word deur die feit dat geen variasie in sinsvorm vereis word nie, en dit dus ' $n$ minder komplekse sinstruktuur as dié met 'n laer voorkomsfrekwensie is (Heider en Heider, 1940). Die ingebedde, onderskikkende en passiewe sinne vereis egter ' $n$ variasie in sinstruktuur, byvoorbeeld woordvolgorde, en dit is dus 'n meer komplekse sin (Russel et al. 1976). Powers en Wilgus (1983) meen dat ingebedde, onderskikkende, passiewe, ontkennings- en vraagsinne almal 'n vorm van komplekse sinstrukture is, en die verkreë resultate van hierdie studie stem dus ooreen met die van Powers en Wilgus (1983).

'n Totale persentasie van 45,1 van alle sinne wat tydens geskrewe taal gebruik is, was van die sewe sintipes wat vir die ondersoek uitgesonder is. Hiervan is $43,5 \%$ korrek gebruik. Die hoë persentasie direkte-rede-sinne wat gebruik is, kan moontlik verklaar word op grond van die feit dat die direkte rede die taalvorm is wat elke dag tydens kommunikasie gebruik word. Dit lyk asof die gehoorgestremde proefpersone in die direkte-rede-styl wat vir hulle bekend is, praat of 'n storie vertel. Geen variasie in sinsvorm is nodig tydens direkte rede nie, wat ook moontlik verder bydra tot die hoë voorkoms hiervan. Neweskikkende $(12,7 \%)$ en ontkenningsinne $\{9,8 \%\}$ kom daar waarskynlik met ' $n$ hoë persentasie 
voor omdat geen variasie in sinsvorm vereis word nie. Neweskikkende sinne sluit ook die gebruik van die voegwoord "en" in, en volgens Schwartz en Solot (1980) is "en" een van die eerste en mees algemene voegwoorde wat deur die gehoorgestremde kind gebruik word. Volgens Schmitt $(1970)$ is die gehoorgestremde kind nie geneig om passiewe sinne, ontkenningsinne of enige ander sinne wat variasie in vorm vereis, te gebruik nie. Simmons (1962) meen ook dat die gehoorgestremde min buigbaarheid toon ten opsigte van sinstrukture, en die afwesigheid van sinne soos die passiewe vorm of ingebedde sin in die resultate kan moontlik hieraan toegeskryf word. Die produksie van saamgestelde sinne is vir die gehoorgestremde kind moeilik en daarom word kort eenvoudige sinne gebruik, wat die klein persentasie $(2 \%)$ onderskikkende sinne van die resultate verklaar (Lewis en Wilcox, 1978). Pressnell (1973) is van mening dat die gehoorgestremde se bemeestering van sintaksis in gesproke taal vertraag is, en sy bevindinge word gestaaf deur huidige bevindinge.

'n Vergelyking van die proefpersone se geskrewe en gesproke taal na aanleiding van die resultate wat in Tabelle 2,3 en 4 verskaf is, dui op die volgende ooreenkomste:

- Die resultate van beide die geskrewe en gesproke taal het getoon dat ingebedde sinne nie deur die proefpersone gebruik is nie. Dit is aan die kompleksiteit van die sinstruktuur toegeskryf, asook aan die feit dat die sintaktiese reëls vir hierdie struktuur nog nie bemeester is nie. Tyack (1981) is van mening dat ' $n$ kind met taalprobleme, probleme sal hê met komplekse sinne, en dat die kind die reëls van eenvoudige sinstrukture sal toepas wanneer hy met komplekse sinne in aanraking kom. Die afleiding word dus gemaak dat gehoorgestremdes vertraagde taalverwerwing vertoon.

- Slegs $1,3 \%$ van die sinne in geskrewe taal was passiewe sinne en $0 \%$ tydens gesproke taal; dus 'n baie lae voorkomsfrekwensie van die passiewe struk. tuur. Volgens Power en Quigley (1973) en Wiig en Semel $(1980)$ toon die gehoorgestremde 'n groot agterstand met betrekking tot die verwerwing van die passiewe sinsvorm en die huidige resultate bevestig hierdie bevindinge.

- Neweskikkende $(12,7 \%$ en $16,5 \%$ onderskeidelik) en ontkenningsinne $(9,8 \%$ en $6,3 \%$ onderskeidelik) kom in sowel gesproke as geskrewe taal relatief baie voor in vergelyking met ander tipe sinstrukture, waarskynlik omdat dit nie sulke komplekse sinstrukture is nie en geen variasie in sinsvorm vereis word nie. Heider en Heider (1940) het bevind dat die gehoorgestremde tydens geskrewe taal 'n groter aantal eenvoudige sinne gebruik, (wat dus geen variasie in sinsvorm vereis nie\}, maar volgens die verkreë resultate blyk dit die geval vir geskrewe sowel as gesproke taal te wees.

Die volgende verskille is tydens die vergelyking van die geskrewe en gesproke taal van die proefpersone opgemerk:

- Meer onderskikkende $(6,3 \%)$ en neweskikkende $(16,5 \%)$ sinne is in geskrewe as gesproke taal $(2 \%$ en $12,7 \%$ onderskeidelik) gebruik. 'n Moontlike verklaring hiervoor is dat meer tyd benut kan word tydens geskrewe taal om die sinstruktuur te beplan, terwyl gesproke taal vereis dat die spreker sy boodskap vin- nig moet beplan en verbaliseer. Volgens Northcott [1977) word die gehoorgestremde kind in gespreksituasies met kort, grammatikaal korrekte sinne deur sy ouers en onderwysers gestimuleer, wat dan moontlik aanleiding gee tot die gebruik van eenvoudige sinne in gesproke taal. Tydens opleiding in die skool word daar heelwat aandag aan geskrewe taal gegee, wat dus ook 'n moontlike invloed op verkreë toetsresultate kon hê.

- Meer ontkenningsinne is in gesproke taal as in geskrewe taal gebruik $(9,8 \%$ teenoor $6,3 \%)$, waarskynlik omdat alle kinders in die alledaagse lewe te doen kry met sinne wat ontkenning of negatiwiteit oordra byvoorbeeld in die skool of tuis sal woorde soos nie, moenie en nee, dikwels gebruik word). Hierdie ontkenningsinne word dan weer deur die gehoorgestremde kind tydens gesproke taal gebruik. Hart en Rosenstein (1966) is ook van mening dat die gehoorgestremde kind se taal sy linguistiese opvoeding wat hy van sy ouers en onderwysers ontvang, reflekteer.

- Meer vraagsinne (3\%) en meer direkte rede $(17,6 \%)$ is in gesproke taal as geskrewe taal $\{1,3 \%$ en $1,3 \%$ onderskeidelik) gebruik. In 'n skoolopset word die beantwoording van vrae dikwels van die gehoorgestremde kind vereis, en omdat vrae ' $n$ persoon in staat stel om meer inligting van sy luisteraar te verkry, kan die hoë voorkomsfrekwensie van vraagsinne tydens gesproke taal moontlik met hierdie stelling verklaar word. Die direkte rede is ' $n$ taalstruktuur wat tydens alledaagse kommunikasie gebruik word, en dit wil dus voorkom asof die gehoorgestremde kind hierdie bekende struktuur ook in sy gesproke taal toepas; met ander woorde, direkte rede word nie herlei tot indirekte rede nie, aangesien die direktè-rede-struktuur meer bekend is vir die gehoorgestremde kind. Hierdie verklaring sluit dus weer eens aan by Hart en Rosenstein (1966) se bewering, soos vroeër vermeld.

- Tydens geskrewe taal is die direkte rede $100 \%$ korrek gebruik, maar tydens gesproke taal is dit slegs in $5,6 \%$ van die gevalle korrek gebruik. Hierdie diskrepansie kan moontlik toegeskryf word aan ' $n$ tekort aan ouditiewe toevoer tydens gesproke taal, wat dan die lae persentasie korrekte gebruik van die direkte-redestruktuur verklaar. Tydens kommunikasie deur middel van skryftaal is visuele toevoer egter die belangrik. ste sisteem wat as kontrolemeganisme dien, en dit bied 'n moontlike verklaring vir die $100 \%$ korrektheid wat voorkom (Myklebust, 1964).

- Tydens gesproke taal is onderskikkende en vraagsinne $100 \%$ korrek gebruik, terwyl slegs $2 \%$ en $0 \%$ onderskeidelik van hierdie sinstrukture tydens geskrewe taal korrek gebruik is. Aangesien geskrewe taal eers vanaf 'n latere ouderdom aangeleer word, kan verkreë resultate moontlik op grond hiervan verklaar word.

- Tydens gesproke taal kom daar by $6,5 \%$ van die geevalueerde sinstrukture woordvolgordeprobleme voor, teenoor die $3,8 \%$ in geskrewe taal. Volgens Wiig en Semel (1980) dui woordvolgórdefoute op 'n subtiele prosesseringsprobleem by die gehoorgestremde se taal. Schwartz en Solot (1980) beweer dat die gehoorgestremde se woordvolgordegebruik beter in gesproke 
taal as in geskrewe taal sal wees, aangesien mislukkings voorkom kan word deur die gebruik van pouses. Dit lyk egter asof die gehoorgestremde proefpersone in hierdie eksperiment nie in staat is tot die produksie van korrekte woordvolgorde nie, as gevolg van 'n onsekerheid omtrent korrekte woordvolgorde of 'n swak bemeestering van interne taalreëls [Schwartz en Solot, 1980).

- Foutiewe sinsvorme (Tabel 4) het telkens meer tydens geskrewe $\{3,8 \%$ en $1,3 \%$ onderskeidelik $)$ as gesproke taal $\{2 \%$ en $0 \%$ onderskeidelik $\rangle$ voorgekom. Die gehoorgestremde kind is nie daartoe in staat om die korrekte grammatika wat hy tydens gesproke taal aanwend in geskrewe taal toe te pas nie (Bastable in Arnold, Crossley en Exley, 1982).

Wanneer die resultate van geskrewe en gesproke taal samevattend beskou word volgens die inligting in Tabelle 2, 3 en 4 vervat, word opgemerk dat die sewe sinstrukture wat geëvalueer is, $32,9 \%$ van die sinstrukture wat tydens geskrewe taal gebruik is, uitmaak teenoor die $45,1 \%$ tydens gesproke taal. Dit lyk dus asof daar meer komplekse sinstrukture in gesproke as in geskrewe taal voorkom. Tydens geskrewe taal is $65,4 \%$ van die sinstrukture egter korrek gebruik, teenoor die $43,5 \%$ tydens gesproke taal, dit wil sê meer van die komplekse sinstrukture word in gesproke taal gebruik, maar ' $n$ groter aantal korrekte sinne kom tydens geskrewe taal voor. Hierdie huidige resultate stem dus nie ooreen met dié van Arnold, Crossley en Exley [1982] se bevinding dat die gehoorgestremde meer foute tydens die skryf van sintaktiese eenhede maak as wanneer hulle praat nie. Die verkreë resultate stem egter ooreen met dié van Kretschmer en Kretschmer (1978) wat noem dat die gehoorgestremde relatief min komplekse sinne in beide geskrewe en gesproke taal gebruik. Resultate word verder ondersteun deur die bevindinge van navorsers soos Ivimey (1976); Wilbur, Goodhart en Montandon (1983) en Bunch (1979).

\section{2 , Woordvolgorde}

Die tweede afdeling in die evaluering van sintaksis, is woordvolgorde. Foute wat deur die proefpersone gemaak is met betrekking tot woordyolgorde, word in Tabel 5 uiteengesit.

Tabel 5: Resultate ten opsigte van proefpersone se woordvolgordefoute

\begin{tabular}{|l|c|c|}
\hline & $\begin{array}{c}\text { Geskrewe taal } \\
\text { \% foute }\end{array}$ & $\begin{array}{c}\text { Gesproke taal } \\
\text { \% foute }\end{array}$ \\
\hline $\begin{array}{l}\text { \% woordvolgordefoute } \\
\text { gemaak in alle } \\
t \text {-eenhede } \\
\text { \% woordvolgordefoute } \\
\text { gemaak tydens sin- } \\
\text { strukture geëvalueer } \\
\text { (raadpleeg Tabel 3) }\end{array}$ & 5,1 & 4,0 \\
\hline
\end{tabular}

Volgens Tabel 5 kom woordvolgordefoute by $5,1 \%$ van alle sinne in geskrewe taal voor, en by $3,8 \%$ van die sewe geskrewe sinstrukture soos igeëvalueer (kyk ook Tabel 4).

Foute met woordvolgorde is gemaak tydens die gebruik van twee verledetydsinne, asook by passiewe sinne. Die woordsoort wat die grootste voorkoms van woordvolgordeprobleme veroorsaak, is die werkwoord. Uit 'n kwalitatiewe analise blyk dit dat die voornaamwoord "wat" verwarring veroorsaak aangesien woordvolgordefoute ook in teenwoordigheid hiervan voorkom.

Tydens gesproke taal het die proefpersone by $4 \%$ van alle sinne woordvolgordefoute vertoon, en woordvolgordefoute by $6,5 \%$ van komplekse sinstrukture (Tabel 5 ).

Kwalitatiewe analise van die resultate dui daarop dat woordvolgordefoute tydens die gebruik van die direkterede-struktuur, 'n neweskikkende sin, verledetydsvorm, en 'n ontkenningsin voorkom; dit wil sê, meestal die sinne wat variasie in sinsvorm vereis en dus meer kompleks is. Soos reeds vroeër genoem, het navorsing bewys dat die gehoorgestremde kind probleme met komplekse sinstrukture ondervind (Heider en Heider, 1940; Simmons, 1962).

Uit Tabel 5 blyk dit dus dat meer probleme met woordvolg. orde tydens geskrewe taal $(5,1 \%)$ as in gesproke taal $(4 \%)$ voorkom. 'n Moontlike verklaring hiervoor is dat geskrewe taal eers aangeleer word op ' $n$ heelwat later stadium as die gesproke taal, en dus is die gehoorgestremde kind nog nie so vaardig in korrekte ordening van woorde as byvoorbeeld ty. dens gesproke taal wat elke dag vanaf geboorte gehoor word nie (alhoewel tot ' $n$ beperkte mate by die gehoorgestremde kind). Verskeie navorsers op die gebied van kindertaalontwikkeling huldig die mening dat die posisie van woorde in ' $n$ sin belangrik is ten opsigte van betekenisvolheid en dat woordvolgorde reeds op 'n vroeë stadium van taalontwikkeling ' $n$ meganisme is wat betekenis uitdruk (Sinclair en Bronckart, 1972; Brown, 1973; Bloom, 1970). Volgens Brown en Bellugi (1964) is dit moontlik dat die normaal horende kind normale woordvolgorde behou, omdat hy bepaalde semantiese verhoudings daardeur wil uitdruk. Moontlik kan hierdie genoemde stelling dan ook dien as motivering waarom minder woordvolgordeprobleme tydens gesproke taal deur die proefpersone gemaak is as tydens geskrewe taal. Tydens die gebruik van meer komplekse sinstrukture (Tabel 2), is daar egter $6,5 \%$ woordvolgordefoute in gesproke taal; teenoor die $3,8 \%$ tydens geskrewe taal gemaak. Die moontlikheid is reeds genoem dat die gehoorgestremde kind tydens geskrewe taal meer tyd gegun word om die sinstruktuur te beplan as tydens gesproke taal, en daarom die kleiner persentasie woordvolgordefoute in kom. plekse geskrewe sinstrukture.

Celliers (1981) is van mening dat die kommunikasiewaarde van woordvolgorde vir normaal horende kinders op verskillende taalontwikkelingstadiums verskil, en aangesien die gehoorgestremde meestal 'n agterstand toon in die verwerwing van taal (Presnell, 1973), kan ons verwag dat hierdie aspek nie vergelykbaar sal wees by die twee groepe nie. Pressnell (1973) beweer dat die gehoorgestremde kind se bemeestering van sintaksis in gesproke taal vertraag is, en dit word dan bevestig deur die hoë persentasie woordvolgordefoute in die gebruik van komplekse sinstrukture. ' $n$ Verdere verklaring vir bogenoemde verskynsel mag wees dat die gehoorgestremde kind nie werklik oor die nodige begrip vir komplekse sinne beskik nie, en dus verward raak in die gebruik daarvan. Dit is ook moontlik dat die toepaslike sintaktiese reëls nog nie bemeester is nie. 
des se woordvolgordegebruik met diê van die gehoorgestremde kind vergelyk word, kan woordvolgordeprobleme aan die hand van die volgende verklaar word:

- Dit is moontlik dat die gehoorgestremde kinders nie die semantiese betekenis van uitinge volkome insien nie, en daarom is woordvolgorde nie vir hulle so belangrik nie.

- $\quad$ 'n Tweede moontlikheid is dat die gehoorgestremde kinders nie oor die sintaktiese vermoë beskik om te weet wat die korrekte woordvolgorde is nie.

- Dit blyk ook moontlik te wees dat die kommunikasiewaarde van woordvolgorde vir die gehoorgestremde kinders nie van soveel belang is nie.

- Laastens bestaan die moontlikheid dat die gehoorgestremde kinders ' $\mathrm{n}$ agterstand vertoon met betrekking tot die ontwikkelingsverloop van woordordereëls, aangesien soveel foutiewe sinstrukture ook tydens hierdie eksperiment waargeneem is (Celliers, 1981).

\section{SAMEVATTING}

'n Vergelyking van die proefpersone se geskrewe en gesproke sintaktiese vermoëns het op die volgende OOREENKOMSTE gedui, naamlik:

- Die resultate van beide die geskrewe en gesproke taal het getoon dat ingebedde sinne nie deur die proefpersone gebruik is nie.

- Slegs $1,3 \%$ van die sinne in geskrewe taal was passiewe sinne en $0 \%$ tydens gesproke taal; dus ' $n$ baie lae voorkomsfrekwensie van die passiewe sinstruktuur, wat ooreenstem met bevindinge van Powers en Quigley (1973).

- Neweskikkende $(12,7 \%$ en $16,5 \%$ onderskeidelik $)$ en ontkenningsinne $\{9,8 \%$ en $6,3 \%$ onderskeidelik $\}$ kom in sowel gesproke as geskrewe taal relatief baie voor in vergelyking met ander tipes sinstrukture.

Die volgende VERSKILLE is tydens die vergelyking van geskrewe en gesproke sintaktiese vermoërs opgemerk, naamlik:

- Meer onderskikkende $(6,3 \%)$ en neweskikkende $(16,5 \%)$ sinne is in geskrewe as gesproke taal $\{2 \%$ en $12,7 \%$ onderskeidelik) gebruik.

- Meer ontkenningsinne is in gesproke taal as in geskrewe taal gebruik $\{9,8 \%$ teenoor $6,3 \%\}$.

- Meer vraagsinne $\{3 \%\}$ en baie meer direkte rede

. $\quad(17,6 \%)$ is in gesproke taal as geskrewe taal $(1,3 \%$ en $1,3 \%$ onderskeidelik/gebruik.

- Tydens geskrewe taal is die direkte rede $100 \%$ korrek gebruik, maar tydens gesproke taal is dit slegs $5,6 \%$ van die gevalle korrek gebruik.

- Tydens gesproke taal is onderskikkende en vraagsinne $100 \%$ korrek gebruik, terwyl slegs $2 \%$ en $0 \%$ on- derskeidelik van hierdie sinstrukture tydens geskrewe taal korrek gebruik is.

- Tydens gesproke taal kom daar by $6,5 \%$ van die geëvalueerde sinstrukture woordvolgordeprobleme voor, teenoor die $3,8 \%$ in geskrewe taal. Die persentasie woordvolgordefoute gemaak in alle t-eenhede is egter $5,1 \%$ in geskrewe taal, teenoor die $4,0 \%$ in gesproke taal.

Op grond van die resultate van hierdie ondersoek as geheel kan die volgende gevolgtrekkings gemaak word, naamlik:

Meer komplekse sinstrukture het tydens die proefpersone se gesproke taal voorgekom as wat in geskrewe taal gebruik is.

- Die persentasie korrekte sinstrukture wat gebruik is, is egter groter in geskrewe taal as in gesproke taal alhoewel nogtans betreklik laag.

- Meer woordvolgordefoute is tydens geskrewe as gesproke taal gemaak.

- Die diskrepansie wat tussen die resultate van gesproke en geskrewe taal voorkom, mag 'n direkte gevolg van die onderrigwyses van die proefpersone wees waar gesproke taal as kommunikasiemedium aangeleer word en geskrewe taal bloot as 'n meganiese funksie aangeleer word.

Kretschmer en Kretschmer (1978) se bevinding dat die gehoorgestremde kind min komplekse sinstrukture in gesproke en geskrewe taal gebruik, ondersteun dus die resultate van hierdie studie.

Aangesien dit blyk asof die gehoorgestremde proefpersone 'n onvermoë ten opsigte van die gebruik van komplekse sinstrukture toon, word aanbeveel dat meer blootstelling van die gehoorgestremde kinders hieraan nodig is. Aangesien gehoorgestremde kinders in 'n voorgeskrewe skoolprogram opgeneem is en blootstelling in ' $n$ groot mate bepaal word deur die kurrikulum wat gevolg word, is dit ' $n$ belangrike faktor wat in aanmerking geneem moet word. Die gebruik van komplekse sinstrukture en die korrektheid vian woordvolgorde in die taal van gehoorgestremdes is egter.' 'n navorsingsgebied wat verdere indringende aandag moet geniet.

\section{SLOT}

Die inligting wat tydens hierdie studie verkry is, hou belangrike implikasies in vir die evaluering en behandeling van die gehoorgestremde kind, deurdat meer insig omtrent die gehoorgestremde se gesproke en geskrewe sintaktiese vermoëns verkry is. Navorsing op hierdie gebied lê egter nog braak, en die huidige studie is die eerste poging in Afrikaans om die verband tussen geskrewe en gesproke sin. taktiese vermoëns uit te lig. Waardevolle riglyne vir die evaluering en behandeling van gehoorgestremde'kinders is egter vekry. Die studie kan dus as vertrekpunt dien vir verdere navorsing.

\section{VERWYSINGS}

Arnold, P. 1978. The Deaf Child's Written English - Can We Measure Its Quality? Journal British Association of Teachers of the Deaf, 2 (6), 196-199. 
Arnold, P., Crossley, E. and Exley, S. 1982. Deaf Children's Speaking, Writing, Comprehension of Sentences. The Journal of Auditory Research, 22, 225-232.

Bloom, L. 1970. Language Development : Form and Function in Emerging Grammars, Cambridge, Mass: MIT Press.

Bloom, L. and Lahey, M. 1978. Language Development and Language Disorders, New York: John Wiley and Sons, Inc.

Brown, R. 1973. A First Language: The Early Stages, Cambridge: Harvard University Press.

Brown, R. and Bellugi, U. 1964. Three Processes in the Child's Acquisition of Syntax. Harvard Educational Review, 3, 133-151.

Bunch, G.O. 1979. Degree and Manner of Acquisition of Written English Language Rules by the Deaf. American Annals of the Deaf, 124 (1), 10-15.

Celliers, A.S. 1981. Die Ontwikkeling van Woordordereëls in Sekere Sintaktiese Strukture by die Jong Afrikaanse Kind. Ongepubliseerde M-verhandeling, Universiteit van Pretoria.

Davis, J.M. and Hardick, E.J. 1981. Rehabilitative Audiology for Children and Adults, New York: John Wiley and Sons.

Hart, B. and Rosenstein, J. 1966. Examining the Language Behavior of Deaf Children. The Volta Review, 66, 679-683.

Heider, F. and Heider, G.M. 1940. A Comparison of the Sentence Structure of Deaf and Hearing Children. Physiological Monographs, 52, 42-102.

Ivimey, G.P. 1976. The Written Syntax of an English Deaf Child: an Exploration in Method. British Journal of Disorders of Communication, 11 (2), 103-120.

Kretschmer, R.R and Kretschmer, L.W. 1978. Language Development and Intervention with the Hearing Impaired. Baltimore: University Press.

Lewis, T. and Wilcox, J. 1978. The Perceptual use of Semantic Rules by Normal Hearing and Hard-of-Hearing Children. Journal of Communication Disorders, 11, 107-118.

Myklebust, H.R. 1964. The Psychology of Deafness, New York, Grune and Stratton

Myklebust, H.R. 1965. Development and Disorders of Written Language. (Volume 1) Picture Story Language Test, New York: Grune and Stratton

Northcott, W.H. 1977. Curriculum Guide. Hearing Impaired-Children and Their Parents, Washington: Alexander Graham Bell Association for the Deaf, Inc.
Power, D.J. and Quigley, S.P. 1973. Deaf Children's Acquisition of the Passive Voice. Journal of Speech and Hearing Research, 16, 5-11.

Powers, A.R. and Wilgus, S. 1983. Linquistic Complexity in the Written Language of Hearing-Impaired Children. The Volta Review, 85 (4), 201-210.

Pressnell, L.M. 1973. Hearing-Impaired Children's Comprehension and Production of Syntax in Oral Language. Journal of Speech and Hearing Research, 16, 12-21.

Quigley, S.P., Montanelli, D.S. and Wilbur, R.B. 1976. Some Aspects of the Verb System in the Language of Deaf Students. Journal of Speech and Hearing Research, 19, 536-550.

Russel, W.K. Quigley, S.P. and Power, D.J. 1976. Linguistics and Deaf Children, Washington: Alexander Graham Bell Association for the Deaf, Inc.

Schmitt, P.J. 1970. Deaf Children's Comprehension and Production of Sentence Transformations and Verb Tenses. Unpublished Doctoral Dissertation, University Microfilms, Ann Arbor, Michigan.

Schwartz \&.R. and Solot, M. 1980. Response Patterns Characteristic of Verbal Expressive Disorders. Language, Speech and Hearing Services in Schools. 11, 139-144.

Simmons, A.A. 1962. A Comparison of the Type Token Ratio of Spoken and Written Language of Deaf and Hearing Children. The Volta Review, 64, 417-421.

Sinclair, H. and Bronckart, J.P. 1972. SVO a Linguistic Universal? A Study in Development Phsycholinguistics. Journal of Experimental Child Psychology, 14 [3], 329-348.

Steinkamp, M.W. and Quigley, S.P. 1977. Assessing Deaf Children's Written Language. The Volta Review, 8, 7-13.

Tyack, D.L. 1981. Teaching Complex Sentences. Language, Speech and Hearing Services in Schools, 12, 49-56.

Wiig, E.H. and Semel, E.M. 1980. Language Assessment and Intervention for the Learning Disabled, Columbus, Ohio: Charles E. Merrill Publishing Company.

Wilbur, R., Goodhart, W. and Montandon, E, 1983. Comprehension of Nine Syntactic Structures by Hearing-Impaired students. The Volta Review, 85 |7|, 328-345. 


\section{BYLAE}

TOETS VIR DIE EVALUERING VAN AFRIKAANSSPREKENDE GEHOORGESTREMDE KINDERS SE EKSPRESSIEWE GESKREWE EN GESPROKE TAALVERMOËNS

\section{A. TAALVORM}

1. SINTAKSIS

a) Sinstrukture

\begin{tabular}{|l|l|l|}
\hline Sinstrukture & Geskrewe Taal & Gesproke Taal \\
\hline
\end{tabular}

Ingebedde sin

* Aantal

- Woordvolgorde foutief

" Korrek

Onderskikkende sin

* Aantal

* Woordvolgorde foutief

* Korrek

Neweskikkende sin

* Aantal

* Woordvolgorde foutief

* Korrek

Vraagsin

* Aantal

* Woordvolgorde foutief

* Korrek

Ontkenningsin

* Aantal

- Woordvolgorde foutief

* Korrek

Direkte-rede-sin

* Aantal

* Woordvolgorde foutief

* Korrek

Passiewe sin

* Aantal

* Woordvolgorde foutief

* Korrek

\begin{tabular}{|l|l|l|}
\hline FOUTIEWE SINSVORME & Geskrewe taal & Gesproke taal \\
\hline
\end{tabular}

Onvoltooide sinne

Tyd - vorm foutief

b) Woordvolgorde

\begin{tabular}{ll}
\hline t-eenheid nommer & $\begin{array}{l}\text { Geskrewe taal } \\
\text { t-eenheid nommer }\end{array}$ \\
\hline
\end{tabular}

2. MORFOLOGIE

\begin{tabular}{|l|l|l|}
\hline Morfologiese verbuigings & Geskrewe taal & Gesproke taal \\
\hline
\end{tabular}

* Aantal

* Byvoegings

* Vervangings

* Weglatings

\section{FONETIEK}

\begin{tabular}{|c|c|c|c|c|c|c|}
\hline $\begin{array}{c}\text { Taal- } \\
\text { media }\end{array}$ & $\begin{array}{c}\text { Korrekte } \\
\text { woord }\end{array}$ & $\begin{array}{c}\text { Foutiewe } \\
\text { woord }\end{array}$ & $\begin{array}{c}\text { Tipe } \\
\text { fout }\end{array}$ & $\begin{array}{c}\text { Verlang- } \\
\text { de klank } \\
\text { of skrif- } \\
\text { simbool }\end{array}$ & $\begin{array}{c}\text { Gelewer- } \\
\text { de klank } \\
\text { of skrif- } \\
\text { simbool }\end{array}$ & $\begin{array}{c}\text { Posi- } \\
\text { sie in } \\
\text { woord }\end{array}$ \\
\hline
\end{tabular}

Geskrewe

taal

Gesproke

taal

\section{B. TAALINHOUD}

1. PRODUKTIWITEIT

Aspekte van taalinhoud Geskrewe taal Gesproke taal geëvalueer

a) Totale aantal woorde

b) Totale aantal teenhede

c) Woorde per t-eenheid

\section{WOORDSOORTE}

\begin{tabular}{|c|c|c|}
\hline & Geskrewe taal & Gesproke taal \\
\hline Woordsoorte & A $B \quad C \quad D$ & $A \quad B \quad C \quad D$ \\
\hline
\end{tabular}

Werkwoord

Hulpwerkwoord van tyd

Modale hulpwerkwoord

Koppelwerkwoord

Selfstandige naamwoord

Voegwoord

Voorsetsel

Voornaamwoord

Bywoord

Lidwoord

A - Aantal

B - Byvoeging

$\mathrm{C}$ - Vervanging

D - Weglating

\section{AARD VAN TAALINHOUD}

\begin{tabular}{|l|l|l|}
\hline$t$-eenheid nommer & Geskrewe taal & Gesproke taal \\
\hline
\end{tabular}

1.

2.

3.

4.

5.

6.

7.

8.

9.

10.

11.

12.

13.

14.

15.

16.

17.

18.

19. 
20.

40.
OPSOMMEND:

Aard van taalinhoud Geskrewe taal Gesproke taal

Vlak 1

Vlak 2

Vlak 3

Vlak 4

C. AANVULLENDE INLIGTING

a) Behoud van tema

b) Herhaling van vorige idees

c) Selfkorreksie

d) Gebruik van selfstandige naamwoorde in plaas van voornaamwoorde

e) Gebruik van inleidende en slotsinne

f) Vooronderstelling

Algemene inligting omtrent taalvorm

Algemene inligting omtrent taalinhoud

Opmerkings

Needler Westdene has been active in the South African hearing market for more than 20 years and therefore fully understands your specific requirements in the areas of:

TESTING of hearing ability

IMPROVEMENT of hearing ability

PREVENTION against industrial noise

SUPPLYING specialised electromedical equipment and tools for

Speech Therapists, ENT's and others.

MAINTENANCE AND REPAIR to and CALIBRATION of all equipment supplied bý Needler Westdene (and certain other suppliers).

Contact us first for:

- Professional advice and guidance

- Competitive quotes for products and consumable items

- The best pre- and post-sales support.

\section{THE NEEDLER WESTDENE ORGANISATION C.C.} (CK87/02503/23)

P.O. BOX 28975

SANDRINGHAM

2131 R.S.A.

TEL: 011-640 5017 

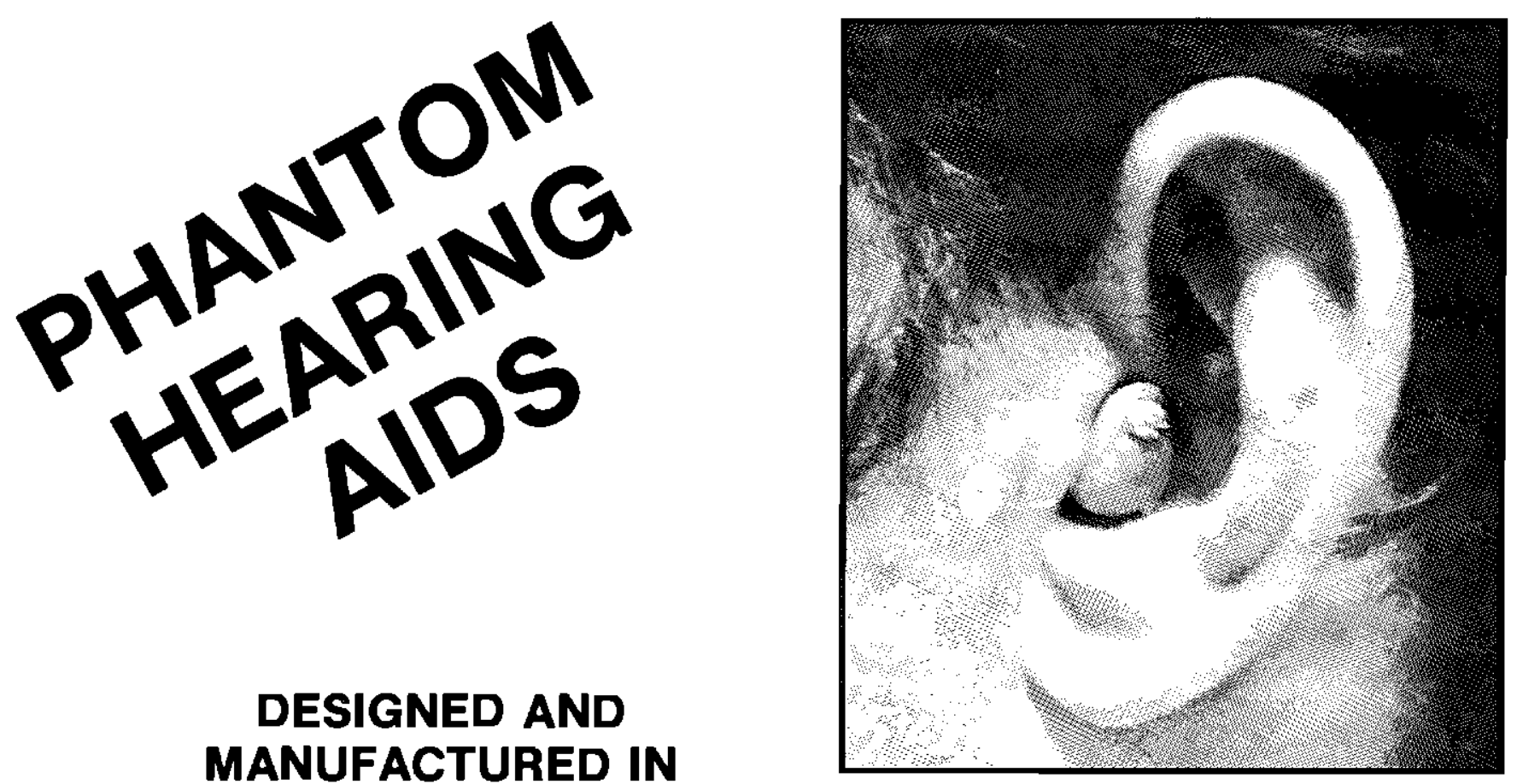

\section{DESIGNED AND \\ MANUFACTURED IN SOUTH AFRICA}

The Phantom Series combines the flexibility of behind-the-ear hearing aids with the acoustic advantages and cosmetic appeal of in-the-ear hearing aids.

A unique construction technique allows various models to be tried and tested in an individually made shell.

Clip-in modules are inserted with no special tools in a few seconds and it is even possible to make acoustic modifications to the earmould for controlling in-situ performance - including "open" earmoulds.

\section{MANUFACTURED BY:}

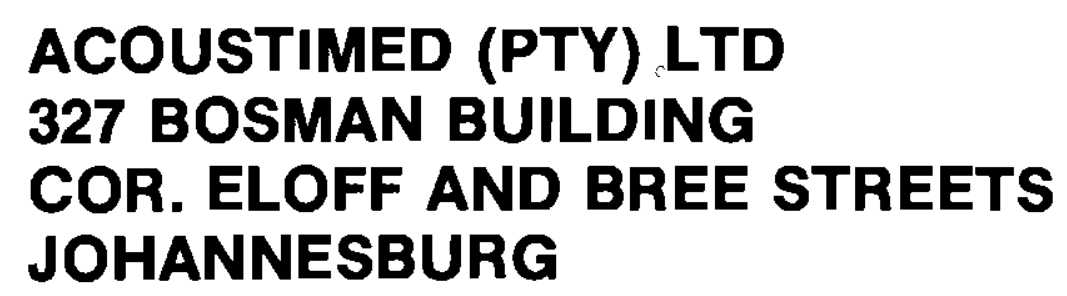

\section{TEL: (011) 337-2977}

